\title{
Sexual Function and Associated Factors in Postmenopausal Women
}

\section{Função sexual e fatores associados em mulheres na pós-menopausa}

\author{
Socorro Rejany Sales Silva Trento ${ }^{1}$ Alberto Madeiro ${ }^{1(}$ Andréa Cronemberger Rufino $^{10}$ \\ 1 Programa de Pós-Graduação em Saúde e Comunidade, Universidade \\ Federal do Piauí, Teresina, PI, Brazil \\ Address for correspondence Alberto Madeiro, Dr., Rua Olavo Bilac, \\ 2335, 64001 280, Centro/ Sul, Teresina, PI, Brazil \\ (e-mail: madeiro@uol.com.br).
}

Rev Bras Ginecol Obstet 2021;43(7):522-529.

\begin{abstract}
Keywords

- sexuality

- sexual dysfunctions

- psychological

- climateric

- women's health

- postmenopause

\section{Resumo}

Objective To assess the sexual function and associated factors in postmenopausal women.

Methods This a descriptive, cross-sectional study with 380 women aged 40 to 65 years, users of public health services in 2019. Questionnaires were applied on demographic characteristics, on climacteric symptoms (menopause rating scale) and on sexual function (sexual quotient, female version). Bivariate and multiple analyses by logistic regression were performed, with adjusted odds ratios $\left(\mathrm{OR}_{\mathrm{ad}}\right)$ and $95 \%$ confidence intervals $(95 \% \mathrm{Cls})$.

Results More than half (243/64\%) of the participating women were at risk of sexual dysfunction, with lower scores in the domains of sexual desire and interest, comfort, orgasm, and satisfaction. Women with a partner $\left(\mathrm{OR}_{\mathrm{ad}} 2.07 ; 95 \% \mathrm{Cl} 1.03-4.17\right)$ and those who reported sleep problems $\left(\mathrm{OR}_{\mathrm{ad}} 2.72 ; 95 \% \mathrm{Cl} 1.77-4.19\right)$, depressed mood ( $\mathrm{OR}_{\mathrm{ad}} 2.03$; $95 \% \mathrm{Cl} 1.32-3.10)$, sexual complaints ( $\mathrm{OR}_{\text {ad }} 8.16$; 95\% CI 5.06-13.15), and vaginal dryness $\left(\mathrm{OR}_{\text {ad }} 3.44 ; 95 \% \mathrm{Cl} 2.22-5.32\right)$ showed greater chance of sexual dysfunction.

Conclusion There was a high prevalence of sexual dysfunction, with the influence of conjugality and climacteric symptoms on sexual function.

Objetivo Avaliar a função sexual e fatores associados em mulheres na pósmenopausa.

Métodos Este é um estudo descritivo, transversal, com 380 mulheres de 40 a 65 anos, usuárias de serviços de saúde públicos em 2019. Foram aplicados questionários sobre características demográficas, sobre sintomas climatéricos (menopause rating scale) e sobre a função sexual (Quociente Sexual, versão feminina). Análises bivariada e múltipla por regressão logística foram realizadas, com cálculo de odds ratio ajustado $\left(\mathrm{OR}_{\mathrm{aj}}\right)$ e intervalos de confiança de $95 \%$ (ICs95\%).
\end{abstract}

received

August 24, 2020

accepted

July 21,2021
DOI https://doi.org/

10.1055/s-0041-1735128. ISSN 0100-7203.
๑) 2021. Federação Brasileira de Ginecologia e Obstetrícia. All rights reserved.

This is an open access article published by Thieme under the terms of the Creative Commons Attribution License, permitting unrestricted use, distribution, and reproduction so long as the original work is properly cited. (https://creativecommons.org/licenses/by/4.0/)

Thieme Revinter Publicações Ltda., Rua do Matoso 170, Rio de Janeiro, RJ, CEP 20270-135, Brazil 
Palavras-chave

- sexualidade

- disfunções sexuais psicogênicas

- climatério

- saúde da mulher

- pós-menopausa
Resultados Mais da metade (243/64\%) das mulheres participantes no estudo apresentou risco de disfunção sexual, com escores mais baixos dos domínios desejo e interesse sexual, conforto, orgasmo e satisfação. Mulheres com companheiro $\left(\mathrm{OR}_{\mathrm{aj}}\right.$ 2,07 ; IC95\% 1,03-4,17) e aquelas que relataram problemas de sono $\left(\mathrm{OR}_{\mathrm{aj}} 2,72\right.$; IC95\% $1,77-4,19)$, ânimo depressivo $\left(O R_{a j} 2,03 ; I C 95 \% 1,32-3,10\right)$, queixas sexuais $\left(O R_{a j}\right.$ 8,16; IC95\% 5,06-13,15) e ressecamento vaginal $\left(\mathrm{OR}_{\mathrm{aj}} 3,44\right.$; IC95\% 2,22-5,32) apresentaram maior chance de disfunção sexual.

Conclusão Houve prevalência elevada de disfunção sexual, com influência da conjugalidade e dos sintomas climatéricos sobre a função sexual.

\section{Introduction}

Sexual function results from the influence of organic, psychological, and interpersonal factors. Psychophysiological or interrelational problems interfere with the sexual function and offer obstacles to sexual satisfaction, which result in sexual dysfunctions. ${ }^{1}$ The sexual function reflects the phases of sexual response, and its assessment can be used as a measure of sexual well-being. ${ }^{2}$ Sexual health care includes the assessment of sexual function, which must also be incorporated into actions developed in basic health care. 2,3

There is a consensus that the human sexual response presents a predictable sequence of somatic and psychological changes, although it may differ between men and women. ${ }^{4}$ The biological aspect of the female sexual response was initially described in four linear and successive phases, ${ }^{5}$ being subsequently characterized by a three-phase model composed of desire, excitement, and orgasm. ${ }^{6}$ In 2001, the value of interpersonal relationships in women's sexuality was highlighted, with the proposition of a female sexual function model with a circular trajectory in which emotional stimuli and relationships play a fundamental role. $^{7}$

Multiple causes can impair female sexual response, leading to sexual dysfunction. Data from a study that evaluated the sex life of Brazilians pointed out, however, that women in a higher age group were the most dissatisfied with their sex life. ${ }^{8}$ The prevalence of sexual dysfunction in women in menopause is high, ranging from 35.9 to $67 \%$ among women from different Brazilian locations. ${ }^{9-12}$ Urogenital changes resulting from hypoestrogenism have the potential to reverberate in postmenopausal sexual function, ${ }^{13}$ changing the domains of desire, excitement, and orgasm, and impacting interpersonal functioning and quality of life. ${ }^{14-16}$

Estrogen interferes with the female sexual function by having a central action in the hypothalamus and preoptic area that leads to a positive influence on motivation, mood, and sexual desire. It also acts directly on the vulva and vagina, increasing genital blood flow and vaginal lubrication. In this way, estrogen works by improving sexual desire and arousal. ${ }^{17}$ Thus, hypoestrogenism can result in less sexual responsiveness by acting on the central nervous system and peripheral tissues. ${ }^{17,18}$ However, observational studies have shown that the relationship with the partner and the state of physical and mental health were more strongly associated with sexual function than the serum estrogen levels. ${ }^{18}$

Some authors point out that poor vaginal lubrication can result in dyspareunia and, consequently, have an impact on the decrease of sexual desire. This can discourage women from participating in sexual relations with their partners or it can be an interference factor in the other phases of female sexual response. ${ }^{19,20}$ The correlation observed between typical symptoms of hypoestrogenism and sexual dysfunction in postmenopausal women reinforces this hypothesis, especially when somato-vegetative and urogenital symptoms are reported. ${ }^{20}$ In addition, the intensity of somato-vegetative and urogenital symptoms has strong association with worse sexual function. ${ }^{12}$

Considering the increase in life expectancy as a current trend, most women spend about a third of their existence in the postmenopausal period. ${ }^{13}$ Thus, sexuality must also receive full attention in the climacteric, since it represents one of the pillars of quality of life and a marker for women's general health. In view of the disorders that sexual dysfunctions may cause, the aim of the present study was to investigate the sexual function and associated factors of postmenopausal women.

\section{Methods}

This is a descriptive and cross-sectional study with postmenopausal women between 40 and 65 years old, residing in the urban region of Teresina, Piauí, and attended at Basic Health Units (BHUs). Piauí is a Brazilian state, located in the Northeast region. For the diagnosis of menopause, the clinical criterion of amenorrhea for a minimum period of 12 months was used. Women who reported absence of sexual practice in the last 6 months of the survey, and those with cognitive and/or neurological changes that could make it difficult to complete the questionnaire were excluded from the study.

For the sample calculation, simple random sampling without replacement was used. A universe of 30,164 women was used, according to the number of women registered in Primary Care in Teresina, within the age group established in the study. A 95\% confidence interval was adopted in the estimates and variance based on the prevalence of sexual dysfunction of $49.6 \%,{ }^{11}$ with a $5 \%$ error in the parameters to be estimated. The final sample size was 380 women. 
The BHU that participated in this study were selected using simple random sampling, limited to $4 \mathrm{BHU}$ in each area of the city (Center/North, South, East/Southeast) until completing the minimum sample size required for the study. Data collection took place from September 2018 to September 2019. The eligible women were randomly selected and invited to participate in the research, and the informed consent form (ICF) was filled out in a reserved room.

Three instruments were used: 1 . questionnaire with sociodemographic data; 2 . questionnaire on menopause symptoms; and 3 . the sexual quotient, female version (SQ-F). First, the following sociodemographic data were collected: age range (40-49; 50-59; 60-65), skin color (black; brown; indigenous; white; yellow), education (years: no; up to $11 ;>11$ ), professional occupation (with occupation; with no occupation), family income (wages: no; up to $2 ;>2$ ), conjugality (no; yes), and use of hormone therapy (no; yes).

Second, a questionnaire on menopause symptoms was applied, known as the menopause rating scale (MRS), already validated and translated in Brazil. ${ }^{21}$ It presents 11 questions in domains of somato-vegetative symptoms (hot flashes, cardiac malaise, sleeping, muscle and joint problems), urogenital (bladder, sexual problems and vaginal dryness) and psychological (depressed mood, irritability, anxiety, physical and mental exhaustion), with answers to each question classified on a severity scale, ranging from zero (absence of symptom) to four (very severe symptom). For the total score, the scores of all domains are added, classifying women as asymptomatic ( $<4$ points), with mild symptoms (from 5-8 points), with moderate symptoms (9-15 points) and with severe symptoms ( $>16$ points).

Finally, to investigate the sexual function, the SQ-F, developed for the Brazilian population, was used. ${ }^{22}$ The questionnaire consists of 10 self-response questions with domains on sexual desire and interest, foreplays, personal arousal, and attunement with the partner, comfort, orgasm, and satisfaction. Each question is answered on a scale of 0 to 5 , with a score obtained by adding the points of all questions (multiplied by 2), and a final score ranging from 0 to 100 . A total score equal to or below 60 is considered a risk of dysfunction sexual. $^{22}$

The data were organized in Windows Office Excel 2010 spreadsheets (Microsoft Corp., Redmond, WA, USA) and later analyzed using the IBM Statistical Package for the Social Sciences (SPSS) for Windows, Version 20.0 (IBM Corp., Armonk, NY USA), and R-Project version 3.0.2 applications (R Foundation for Statistical Computing, Vienna, Austria). The MRS data were analyzed using dimensions that involve menopausal symptoms. The SQ-F information was evaluated by adding the individual scores of the women to assess sexual performance and track sexual dysfunctions. A bivariate analysis was performed using the Pearson chi-square test or the Student $t$ test to associate sociodemographic variables and climacteric symptoms with women's sexual function. To check the abnormality of the quantitative variables, the Kolmogorov-Smirnov test was applied. The effect of the independent variables on the response variable (SQ-F score $\leq 60$ ) was assessed by multiple logistic regression, with adjusted odds ratios ( $\left.\mathrm{ORs}_{\mathrm{ad}}\right)$ and $95 \%$ confidence intervals (95\%CIs). For the inclusion of variables in the logistic model, the criterion of $p<0.20$ was established in the bivariate analysis. In all tests, $p<0.05$ was adopted as a significant difference or association.

The study was approved by the Research Ethics Committee of the Federal University of Piauí (CAAE 95272918.0.0000.5214), in compliance with Resolution 466/12 of the National Health Council.

\section{Results}

Most women were in the 50 to 59 years (68.4\%) age group, had black/brown skin color (85.3\%), up to 11 years of schooling (89.2\%), family income up to 2 minimum wages (77.4\%) and lived with a partner (90.3\%). Only $5.8 \%$ of them used hormone therapy ( $\mathbf{- T a b l e ~} \mathbf{1}$ ).

More than half (64\%) of the women had a total SQ-F score lower than 60 points, characterizing sexual performance and

Table 1 Characterization of women according to sociodemographic variables

\begin{tabular}{|c|c|c|}
\hline Characteristics & $\mathbf{n}$ & $\%$ \\
\hline \multicolumn{3}{|l|}{ Age range (years) } \\
\hline $40-49$ & 48 & 12.6 \\
\hline $50-59$ & 260 & 68.4 \\
\hline $60-65$ & 72 & 18.9 \\
\hline \multicolumn{3}{|l|}{ Skin color } \\
\hline Yellow/indigenous & 8 & 2.1 \\
\hline White & 48 & 12.6 \\
\hline Black/brown & 324 & 85.3 \\
\hline \multicolumn{3}{|l|}{ Education (years) } \\
\hline No & 18 & 4.7 \\
\hline Up to 11 & 339 & 89.2 \\
\hline$>11$ & 23 & 6.1 \\
\hline \multicolumn{3}{|l|}{ Professional occupation } \\
\hline With occupation & 192 & 50.5 \\
\hline With no occupation & 188 & 49.5 \\
\hline \multicolumn{3}{|l|}{ Family income (wages) } \\
\hline No & 14 & 3.7 \\
\hline Up to 2 & 294 & 77.4 \\
\hline$>2$ & 71 & 18.7 \\
\hline Do not know how to inform & 1 & 0.3 \\
\hline \multicolumn{3}{|l|}{ Conjugality } \\
\hline No & 37 & 9.7 \\
\hline Yes & 343 & 90.3 \\
\hline \multicolumn{3}{|l|}{ Use of hormone therapy } \\
\hline No & 358 & 94.2 \\
\hline Yes & 22 & 5.8 \\
\hline
\end{tabular}


Table 2 Sexual function of women, according to the sexual quotient, female version (SQ-F)

\begin{tabular}{llll}
\hline $\begin{array}{l}\text { Sexual performance and } \\
\text { satisfaction }\end{array}$ & Points & $\mathbf{n}$ & $\%$ \\
Good to excellent & $82-100$ & 45 & 11.8 \\
Regular to good & $62-80$ & 92 & 24.2 \\
Unfavorable to regular & $42-60$ & 110 & 29.0 \\
Bad to unfavorable & $22-40$ & 105 & 27.6 \\
Null to bad & $0-20$ & 28 & 7.4 \\
Total & - & 380 & 100.0 \\
Domains & Scores & Average & Level (\%) \\
Sexual desire and interest & $0-15$ & 6.47 & 43.1 \\
Foreplay & $0-5$ & 2.92 & 58.3 \\
Personal & $0-10$ & 5.27 & 52.7 \\
excitement/alignment with & & & \\
partnership & & & \\
Comfort & $0-10$ & 4.34 & 43.4 \\
Orgasm and satisfaction & $0-10$ & 4.66 & 46.6 \\
Total score & $0-100$ & 52.12 & - \\
\hline
\end{tabular}

satisfaction ranging from null to regular, and, therefore, being screened for the presence of sexual dysfunction. The mean total score of the SQ-F was 52.12 points, and the most affected domains were sexual desire and interest (43.1\%), followed by comfort (43.4\%) and orgasm and satisfaction (46.6\%) (-Table 2).
As for the symptoms in the MRS, $98.4 \%$ of women presented some symptoms, and in $38.2 \%$ of them the symptoms were classified as severe (data not shown in the table). The most reported symptoms were muscle/joint problems (75.3\%), anxiety (67.2\%), and sexual problems (64.7\%), with a predominance of the urogenital domain (78.9\%) (-Table 3 ).

- Table 4 shows that the presence of sexual dysfunction was associated with an absence of family income $(p=0.041)$ and the presence of conjugality $(p=0.048)$. There was also a statistically significant association between the psychological, somato-vegetative and urogenital domains with the presence of sexual dysfunction $(p<0.001)$. All symptoms on the MRS scale were associated with the risk of sexual dysfunction $(p<0.001)$ ( - Table 3 ).

Women with a partner $\left(\mathrm{OR}_{\mathrm{ad}} 2.07 ; 95 \% \mathrm{CI} 1.03-4.17\right)$ and those with reports of depressed mood $\left(\mathrm{OR}_{\mathrm{ad}} 2.03 ; 95 \% \mathrm{CI}\right.$ $1.32-3.10)$, sleep problems $\left(\mathrm{OR}_{\mathrm{ad}} 2,72 ; 95 \% \mathrm{CI} 1.77-4.19\right)$, sexual problems $\left(\mathrm{OR}_{\mathrm{ad}} 8.16 ; 95 \% \mathrm{CI} 5.06-13.15\right)$ and vaginal dryness $\left(\mathrm{OR}_{\mathrm{ad}} 3.44 ; 95 \% \mathrm{CI} 2.22-5.32\right)$ showed greater chance of risk of sexual dysfunction ( - Table 5 ).

\section{Discussion}

The postmenopausal period is marked by physical and psychological changes typical of a woman's life. When symptomatic, this phase can have a negative impact on sexuality and, thus, be associated with sexual dysfunctions. ${ }^{13}$ In the present study, $98.4 \%$ of the participating women had climacteric symptoms, especially urogenital symptoms. The high

Table 3 Association of the risk of sexual dysfunction with the domains and symptoms of the menopause rating scale

\begin{tabular}{|c|c|c|c|c|}
\hline \multirow[t]{2}{*}{ Variables } & \multirow{2}{*}{$\begin{array}{l}\text { Present } \\
\text { symptoms } \\
\mathrm{n}(\%)\end{array}$} & \multirow{2}{*}{$\begin{array}{l}\text { Risk of sexual } \\
\text { dysfunction }(S Q-F \leq 60) \\
n(\%)\end{array}$} & \multirow{2}{*}{$\begin{array}{l}\text { Absence of sexual } \\
\text { dysfunction (SQ-F } \geq 62) \\
\mathrm{n}(\%)\end{array}$} & \multirow[t]{2}{*}{$p$-value* } \\
\hline & & & & \\
\hline \multicolumn{5}{|l|}{ Domains } \\
\hline Psychological & $271(71.3)$ & $191(70.5)$ & $80(29.5)$ & $<0.001$ \\
\hline Somatic & 295 (77.6) & $209(70.8)$ & $86(29.2)$ & $<0.001$ \\
\hline Urogenital & 300 (78.9) & $218(72.7)$ & $82(27.3)$ & $<0.001$ \\
\hline \multicolumn{5}{|l|}{ Symptoms } \\
\hline Hot flashes & $221(58.2)$ & $157(71.0)$ & $64(29.0)$ & $<0.001$ \\
\hline Cardiac malaise & $175(46.0)$ & $125(71.4)$ & $50(28.6)$ & $<0.001$ \\
\hline Sleeping problems & $212(55.8)$ & $157(74.1)$ & 55 (25.9) & $<0.001$ \\
\hline Depressed mood & 195 (51.3) & $140(71.8)$ & $55(28.2)$ & $<0.001$ \\
\hline Irritability & $222(58.4)$ & 159 (71.6) & $63(28.4)$ & $<0.001$ \\
\hline Anxiety & $255(67.1)$ & $177(69.4)$ & $78(30.6)$ & $<0.001$ \\
\hline Physical and mental exhaustion & $212(55.8)$ & $157(74.1)$ & $55(25.9)$ & $<0.001$ \\
\hline Sexual problems & $246(64.7)$ & $198(80.5)$ & $48(19.5)$ & $<0.001$ \\
\hline Bladder problems & $69(18.2)$ & $50(72.5)$ & $19(27.5)$ & $<0.001$ \\
\hline Vaginal dryness & $214(56.3)$ & $163(76.2)$ & $51(23.8)$ & $<0.001$ \\
\hline Muscle/joint problems & $286(75.3)$ & $186(65.0)$ & $100(35.0)$ & $<0.001$ \\
\hline
\end{tabular}

*Pearson's chi-square test. 
526 Sexual Function and Associated Factors in Postmenopausal Women Trento et al.

Table 4 Association between the risk of sexual dysfunction and sociodemographic variables

\begin{tabular}{|c|c|c|c|}
\hline \multirow[t]{2}{*}{ Characteristics } & \multirow{2}{*}{$\begin{array}{l}\text { Risk of sexual } \\
\text { dysfunction }(S Q-F \leq 60) \\
n(\%)\end{array}$} & \multirow{2}{*}{$\begin{array}{l}\text { Absence of sexual } \\
\text { dysfunction (SQ-F } \geq 62) \\
n(\%)\end{array}$} & \multirow[t]{2}{*}{$p$-value } \\
\hline & & & \\
\hline \multicolumn{4}{|l|}{ Age range (years) } \\
\hline $40-49$ & $28(58.3)$ & $20(41.7)$ & \multirow[t]{3}{*}{0.620} \\
\hline $50-59$ & $170(65.4)$ & $90(34.6)$ & \\
\hline $60-65$ & $45(62.5)$ & $27(37.5)$ & \\
\hline \multicolumn{4}{|l|}{ Skin color } \\
\hline Yellow/indigenous & $6(75.0)$ & $2(25.0)$ & \multirow[t]{3}{*}{0.725} \\
\hline White & $32(66.7)$ & $16(33.3)$ & \\
\hline Black/brown & $205(63.3)$ & $119(36.7)$ & \\
\hline \multicolumn{4}{|l|}{ Education (years) } \\
\hline No & $11(61.1)$ & 7 (38.9) & \multirow[t]{3}{*}{0.916} \\
\hline Up to 11 & $14(60.9)$ & $9(39.1)$ & \\
\hline$>11$ & $218(64.3)$ & $121(35.7)$ & \\
\hline \multicolumn{4}{|l|}{ Professional occupation } \\
\hline With occupation & $162(66.9)$ & $80(33.1)$ & \multirow[t]{2}{*}{0.108} \\
\hline With no occupation & $81(58.7)$ & $57(41.3)$ & \\
\hline \multicolumn{4}{|l|}{ Family income (wages) ${ }^{a}$} \\
\hline Up to 2 & $194(63.0)$ & $114(37.0)$ & \multirow[t]{2}{*}{0.048} \\
\hline$>2$ & $61(85.9)$ & $10(14.1)$ & \\
\hline \multicolumn{4}{|l|}{ Conjugality } \\
\hline No & $18(48.6)$ & $19(51.4)$ & \multirow[t]{2}{*}{0.041} \\
\hline Yes & $225(65.6)$ & $118(34.4)$ & \\
\hline \multicolumn{4}{|l|}{ Use of hormone therapy } \\
\hline No & $229(64.0)$ & $129(36.0)$ & \multirow[t]{3}{*}{0.975} \\
\hline Yes & $14(63.6)$ & $8(36.4)$ & \\
\hline Total & $243(63.9)$ & $137(36.1)$ & \\
\hline
\end{tabular}

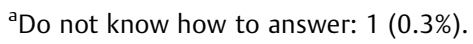

*Pearson chi-square test.

prevalence of climacteric symptoms was also found in a study that evaluated 1,210 women between 45 and 60 years old in São Luís, Maranhão, Brazil, present in $85.9 \%$ of the interviewees, with vaginal dryness being the most prevalent and intense symptom (68.2\%). ${ }^{23}$

The data in this study showed a high prevalence (64.0\%) of sexual dysfunction. Similar findings were also observed in a survey that used the female sexual function index (FSFI) questionnaire in Natal, Rio Grande do Norte, Brazil, which found that $67 \%$ of women had some sexual dysfunction. ${ }^{10}$ In a different way, two other studies showed a lower prevalence of dysfunction sexual. In Recife, Pernambuco, Brazil, when applying the SQ-F to 173 women aged 35 to 65 years, a prevalence of $46.2 \%{ }^{24}$ was observed. In Sergipe, Brazil, when using the FSFI instrument, a prevalence of $42.9 \%$ of sexual dysfunction was observed. ${ }^{12}$

The FSFI is one of the most used validated psychometric scales to assess sexual function. ${ }^{10,12,23,25-27}$ This instrument, validated in Portuguese, contains 19 items with multiple-choice responses to evaluate the sexual function in the 4 weeks prior to answering the questionnaire, and includes 6 domains: desire, arousal, lubrication, orgasm, satisfaction, and pain (dyspareunia). ${ }^{28}$ Unlike the SQ-F, no domain related to the couple's relationship is present in FSFI scale. A Brazilian study with pregnant women showed that moderate-to-strong correlations were obtained between the final scores of FSFI and SQ-F, except for the comfort/pain domain. ${ }^{29}$ However, caution is recommended when comparing results from different populations on different scales of sexual function. ${ }^{30}$

It is known that hypoestrogenism can cause damage to the female sexual response, mainly due to the primordial role it plays on sexual desire, thus predisposing the appearance of sexual dysfunctions. ${ }^{3,25,31}$ In a cross-sectional study, the prevalence was higher for the group of postmenopausal women (53.8\%), when compared with pre-menopausal women (37.9\%). ${ }^{12}$ Other research also corroborated these results, validating the idea that the advent of menopause can 
Sexual Function and Associated Factors in Postmenopausal Women Trento et al. 527

Table 5 Multiple logistic regression for risk of sexual dysfunction associated with sociodemographic characteristics and symptoms of menopause

\begin{tabular}{|c|c|c|c|c|}
\hline Variables & $\mathrm{OR}_{\mathrm{ad}}{ }^{1}$ & $95 \% \mathrm{Cl}^{2}$ & & $p$-value* \\
\hline \multicolumn{5}{|l|}{ Sociodemographic characteristics } \\
\hline Professional occupation & 0.73 & 0.47 & 1.14 & 0.169 \\
\hline Family income & 0.26 & 0.05 & 1.20 & 0.084 \\
\hline Conjugality & 2.07 & 1.03 & 4.17 & $<0.001$ \\
\hline \multicolumn{5}{|l|}{ Symptoms } \\
\hline Hot flashes & 1.12 & 0.658 & 1.910 & 0.674 \\
\hline Cardiac malaise & 1.15 & 0.68 & 1.96 & 0.598 \\
\hline Sleeping problems & 2.72 & 1.77 & 4.19 & 0.001 \\
\hline Depressed mood & 2.03 & 1.32 & 3.10 & 0.041 \\
\hline Irritability & 1.20 & 0.66 & 2.17 & 0.556 \\
\hline Anxiety & 0.86 & 0.47 & 1.58 & 0.623 \\
\hline Physical and mental exhaustion & 1.38 & 0.77 & 2.47 & 0.274 \\
\hline Sexual problems & 8.16 & 5.06 & 13.15 & $<0.001$ \\
\hline Bladder problems & 0.97 & 0.49 & 1.92 & 0.931 \\
\hline Vaginal dryness & 3.44 & 2.22 & 5.32 & $<0.001$ \\
\hline Muscle/joint problems & 0.69 & 0.39 & 1.23 & 0.204 \\
\hline
\end{tabular}

95\% Cl: 95\% confidence interval; OR ad: adjusted odds ratio.

${ }^{*}$ Multivariable logistic regression model.

have a negative impact on sexual function, especially when associated with symptoms typical of this phase of life. ${ }^{26,27,32}$

Like other Brazilian studies, ${ }^{10,24}$ an association was observed between all climacteric symptoms on the MRS scale and sexual function (SQ-F). Among women at risk of sexual dysfunction, there is a higher frequency of hot flashes, depressed mood, sexual problems and vaginal dryness. ${ }^{10}$ Furthermore, there is a significant increase in sexual complaints with the intensification of climacteric symptoms. ${ }^{33}$ There is usually an inverse correlation of climacteric symptoms assessed by MRS scale with sexual function scores, especially when analyzing urogenital symptoms. ${ }^{19}$ In the present study, the use of hormone therapy was not associated with a lower risk of sexual dysfunction. Type, timing, and regular use of hormone therapy were not investigated, and these factors may have an influence on the results found.

The decline in ovarian function, and pituitary changes modify the pelvic tissues and the vaginal mucosa, contributing to the emergence of vaginal dryness, bleeding, and dyspareunia that can have an impact on sexual desire. ${ }^{13,25,31}$ In the present study, sexual desire was the domain that most negatively affected the sexual function of the women interviewed. Hypoactive sexual desire is the most commonly found symptom among female sexual dysfunctions. ${ }^{20,32,34}$ Research data with Colombian women who reported sexual activity in the 4 weeks prior to being asked showed that, also in the postmenopause, sexual desire was the most deteriorated domain. ${ }^{35}$

A data observed in the present study was that the prevalence of sexual dysfunction in women from Teresina, detected by the application of the SQ-F (64.0\%), was similar to the report of sexual problems on the MRS scale (64.7\%), emphasizing that most of the women surveyed had already identified some dissatisfaction in their sex life. It is worth mentioning that the literature suggests that a sexual problem should only be considered as a dysfunction when it causes suffering in the woman's life. ${ }^{34}$ However, some studies bring controversial results when relating the percentages of sexual dissatisfaction on the MRS scale and sexual dysfunction assessed by the SQ-F and FSFI, and sexual dissatisfaction reported by women may be lower than the percentage of sexual dysfunction detected by the FSFI and SQ-F. ${ }^{24,36}$

The presence of conjugality was a factor that significantly increased the chance of sexual dysfunction in women from Teresina. The data available in the literature are not unanimous to support this finding. Sexual problems are very broad concepts which can be caused by biopsychosocial changes. Professional occupation, family income, and conjugality are factors that can affect the sexual response at levels of individual, interpersonal, and social influence. ${ }^{37}$ Although many factors related to conjugality can have an impact on female sexual function, such as sexual compatibility and relationship satisfaction, this study did not make an association between conjugality and specific sexual dysfunction. ${ }^{37}$

Women with sexual partners and a spouse were less likely to have sexual dysfunction in a study with middle-aged Brazilian women with a minimum formal education of 11 years. $^{9}$ Conversely, a cross-sectional study with 412 women in the age group of 40 to 59 years who attended health centers in Santiago, Chile, showed that married women were more likely to experience sexual dysfunction when compared with single women. ${ }^{36}$ The study performed in the state of Pernambuco, Brazil, involving 173 women, 
found no association between conjugality and sexual dysfunction. ${ }^{24}$

Some limitations of the research deserve to be pointed out. First, the women participating in the present study were selected from the users who sought health services and who attended the randomly chosen BHU. Thus, it is not possible to state that the sample may represent the general female population of Teresina, Piauí, Brazil, not covering the entire social and/or cultural variety of the general population of the city. Second, illiterate women with low schooling were included in the present study, since this is a central sociodemographic characteristic of users of the local BHU. For some participants, the questionnaire was read and filled out with the help of a researcher, and this may have generated bias. Third, sexual dysfunctions were not investigated in the participants' partnerships. Male sexual problems, for example, can influence women's sexual lives and interfere with findings of the prevalence of sexual dysfunctions. Finally, several factors interfere with the female sexual response. There are specific climacteric symptoms in the peri and postmenopausal phases. The MRS does not discriminate the somato-vegetative and psychological symptoms at specific climacteric phases. Although this study found an association between the presence of climacteric symptoms and worsening sexual function, we did not associate the symptoms of each climacteric phase with sexual function.

\section{Conclusion}

The data showed a high prevalence of climacteric symptoms and risk of sexual dysfunction among the interviewees, with emphasis on sexual desire and interest. In addition, there was an association between all the symptoms evaluated by the MRS scale with the presence of sexual dysfunction, signaling the importance of the routine investigation of sexual activity in women with symptomatic climacteric. Investigating, informing, and properly treating these women can make the exercise of their sexualities more complete, favoring more pleasure, personal satisfaction, and quality of life.

\section{Contributions}

All authors participated in the concept and design of the present study; analysis and interpretation of data; draft or revision of the manuscript, and they have approved the manuscript as submitted. All authors are responsible for the reported research.

\section{Conflict of Interests}

The authors have no conflict of interests to declare.

\section{References}

1 World Health Organization. Sexual health and its linkages to reproductive health: an operational approach [Internet]. Geneva: WHO; 2017 [cited 2020 Nov 14]. Available from: https://apps. who.int/iris/bitstream/handle/10665/258738/9789241512886eng.pdf? sequence $=1$ \&isAllowed $=\mathrm{y}$
2 World Health Organization. Measuring sexual health: conceptual and practical considerations and related indicators [Internet]. 2010 [cited 2020 Jun 18]. Available from: whqlibdoc.who.int/hq/2010/who_rhr_10.12_eng.pdf

3 Ministério da Saúde. Secretaria de Atenção à Saúde. Departamento de Atenção Básica. Saúde sexual e saúde reprodutiva [Internet]. Brasília, DF: Ministério da Saúde; 2013 [cited 2020 Jun 19]. Available from: https:// bvsms.saude.gov.br/bvs/publicacoes/saude_sexual_saude_reprodutiva. pdf

4 Basson R. Human sexual response. Handb Clin Neurol. 2015; 130:11-18. Doi: 10.1016/B978-0-444-63247-0.00002-X

5 Masters WH, Johnson VE. A resposta sexual humana. São Paulo: Roca; 1984

6 Calabrò RS, Cacciola A, Bruschetta D, et al. Neuroanatomy and function of human sexual behavior: A neglected or unknown issue? Brain Behav. 2019;9(12):e01389. Doi: 10.1002/brb3.1389

7 Basson R. The female sexual response: a different model. J Sex Marital Ther. 2000;26(01):51-65. Doi: 10.1080/009262300278641

8 Abdo CH, Oliveira WM Jr, Moreira ED Jr, Fittipaldi JA. Perfil sexual da população brasileira: resultados do Estudo do Comportamento Sexual (ECOS) do Brasileiro. Rev Bras Med. 2002;59(04):250-257

9 Valadares AL, Pinto-Neto AM, Osis MJ, Sousa MH, Costa-Paiva L, Conde DM. Prevalence of sexual dysfunction and its associated factors in women aged 40-65 years with 11 years or more of formal education: a population-based household survey. Clinics (São Paulo). 2008;63 (06):775-782. Doi: 10.1590/S1807-59322008000600012

10 Cabral PU, Canário AC, Spyrides MH, et al. [Influence of menopausal symptoms on sexual function in middle-aged women]. Rev Bras Ginecol Obstet. 2012;34(07):329-334. Doi: 10.1590/S010072032012000700007 Portuguese

11 Valadares AL, Lui-Filho JF, Costa-Paiva L, Pinto-Neto AM. Middleaged female sexual dysfunction and multimorbidity: a population-based study. Menopause. 2016;23(03):304-310. Doi: 10.1097/GME.000000000000053

12 De Jesus Aquino KS, Prado DS, Santos BR, Carvalho Barreto ID. Fatores associados a disfunções sexuais no climatério. Rev Bras Sex Hum.. 2019;29(02):36-46. Doi: 10.35919/rbsh.v29i2.57

13 Thornton K, Chervenak J, Neal-Perry G. Menopause and Sexuality. Endocrinol Metab Clin North Am. 2015;44(03):649-661. Doi: 10.1016/j.ecl.2015.05.009

14 Santos JL, Leão AP, Gardenghi G. Disfunções sexuais no climatério. Reprod Clim.. 2016;31(02):86-92. Doi: 10.1016/j.recli.2016.08.001

15 Thomas HN, Neal-Perry GS, Hess R. Female sexual function at midlife and beyond. Obstet Gynecol Clin North Am. 2018;45(04): 709-722. Doi: 10.1016/j.ogc.2018.07.013

16 Simon JA, Davis SR, Althof SE, et al. Sexual well-being after menopause: An International Menopause Society White Paper. Climacteric. 2018;21(05):415-427. Doi: 10.1080/13697137.2018.1482647

17 Santoro N, Worsley R, Miller KK, Parish SJ, Davis SR. Role of estrogens and estrogen-like compounds in female sexual function and dysfunction. J Sex Med. 2016;13(03):305-316. Doi: 10.1016/ j.jsxm.2015.11.015

18 Levin RJ, Both S, Georgiadis J, Kukkonen T, Park K, Yang CC. The physiology of female sexual function and the pathophysiology of female sexual dysfunction (Committee 13A). J Sex Med. 2016;13 (05):733-759. Doi: 10.1016/j.jsxm.2016.02.172

19 Rindner L, Strömme G, Nordeman L, et al. Prevalence of somatic and urogenital symptoms as well as psychological health in women aged 45 to 55 attending primary health care: a crosssectional study. BMC Womens Health. 2017;17(01):128. Doi: 10.1186/s12905-017-048-1

20 Wong ELY, Huang F, Cheung AWL, Wong CKM. The impact of menopause on the sexual health of Chinese Cantonese women: A mixed methods study. J Adv Nurs. 2018;74(07):1672-1684. Doi: $10.1111 /$ jan. 13568

21 Heinemann LA, Potthoff P, Schneider HP. International versions of the Menopause Rating Scale (MRS). Health Qual Life Outcomes. 2003;1:28-34. Doi: 10.1186/1477-7525-1-28 
22 Abdo CH. Elaboração e validação do quociente sexual - versão feminina: uma escala para avaliar a função sexual da mulher. Rev Bras Med. 2006;63(09):477-482

23 Malheiros ES, Chein MB, da Silva DS, et al. [Climacteric syndrome in a Northeastern Brazilian city: a household survey]. Rev Bras Ginecol Obstet. 2014;36(04):163-169. Doi: 10.1590/S01007203201400040002 Portuguese

24 Cavalcanti IF, Farias PD, Ithamar L, Silva VM, Lemos A. [Sexual function and factors associated with sexual dysfunction in climacteric women]. Rev Bras Ginecol Obstet. 2014;36(11): 497-502. Doi: 10.1590/S0100-720320140004985 Portuguese

25 Dąbrowska-Galas M, Dąbrowska J, Michalski B. Sexual dysfunction in menopausal women. Sex Med. 2019;7(04):472-479. Doi: 10.1016/j.esxm.2019.06.010

26 Chedraui P, Pérez-López FR, Sánchez H, et al. Assessment of sexual function of mid-aged Ecuadorian women with the 6-item Female Sexual Function Index. Maturitas. 2012;71(04):407-412. Doi: 10.1016/j.maturitas.2012.01.013

27 Cabral PU, Canário AC, Spyrides MH, Uchôa SA, Eleutério J Jr, Gonçalves AK. Determinants of sexual dysfunction among middle-aged women. Int J Gynaecol Obstet. 2013;120(03):271-274. Doi: $10.1016 /$ j.ijgo.2012.09.023

28 Rosen R, Brown C, Heiman J, et al. The Female Sexual FunctionIndex (FSFI): a multidimensional self-report instrument for the assessment of female sexual function. J Sex Marital Ther. 2000;26(02):191-208. Doi: 10.1080/009262300 278597

29 Leite AP, Moura EA, Campos AA, Mattar R, Souza E, Camano L. [Validation of the Female Sexual Function Index in Brazilian preg- nant women]. Rev Bras Ginecol Obstet. 2007;29(08):396-401. Doi: 10.1590/S0100-72032007000800003 Portuguese

30 Giraldi A, Rellini A, Pfaus JG, et al. Questionnaires for assessment of female sexual dysfunction: a review and proposal for a standardized screener. J Sex Med. 2011;8(10):2681-2706. Doi: 10.1111/j.1743-6109.2011.02395.x

31 Crema IL, De Tilio R, Campos MT. Repercussões da menopausa para a sexualidade de idosas: revisão integrativa da literatura. Psicologia (Cons Fed Psicol). 2017;37(03):753-769. Doi: 10.1590/1982-3703003422016

32 Burri A, Hilpert P, Spector T. Longitudinal evaluation of sexual function in a cohort of pre- and postmenopausal women. J Sex Med. 2015;12(06):1427-1435. Doi: 10.1111/jsm.12893

33 Senturk Erenel A, Golbasi Z, Kavlak T, Dilbaz S. Relationship between menopausal symptoms and sexual dysfunction among married Turkish women in 40-65 age group. Int J Nurs Pract. 2015; 21(05):575-583. Doi: 10.1111/ijn.12309

34 Parish SJ, Meston CM, Althof SE, et al. Toward a more evidence-based nosology and nomenclature for female sexual dysfunctions. J Sex Med. 2019;16(03):452-462. Doi: 10.1016/j.jsxm.2019.01.010

35 Monterrosa-Castro A, Márquez-Vega J, Arteta-Acosta C. Disfunción sexual en mujeres climatéricas afrodescendientes del Caribe Colombiano. Iatreia.. 2014;27(01):31-41

36 Figueroa J R, Jara A D, Fuenzalida PA, Del Prado A M, Flores D, Blumel JE. Prevalencia de disfunción sexual en mujeres climatéricas. Rev Med Chil. 2009;137(03):345-350. Doi: 10.4067/S0034-98872009000300004

37 Mark KP, Lasslo JA. Maintaining sexual desire in long-term relationships: a systematic review and conceptual model.J Sex Res. 2018;55 (4-5):563-581. Doi: 10.1080/00224499.2018.1437592 